\title{
The effect of iron availability on the regulation of inorganic carbon acquisition in the coccolithophore Emiliania huxleyi and the significance of cellular compartmentation for stable carbon isotope fractionation
}

\author{
K.G. Schulz ${ }^{\text {a,* }}$, B. Rost ${ }^{\mathrm{b}}$, S. Burkhardt ${ }^{\mathrm{c}}$, U. Riebesell ${ }^{\mathrm{a}}$, S. Thoms ${ }^{\mathrm{b}}$, \\ D.A. Wolf-Gladrow ${ }^{b}$ \\ a Leibniz Institute for Marine Sciences (IFM-GEOMAR), Düsternbrooker Weg 20, 24105 Kiel, Germany \\ b Alfred Wegener Institute for Polar and Marine Research, P.O. Box 12016, 27515 Bremerhaven, Germany \\ ${ }^{\mathrm{c}}$ Molecular Biology and Neurosciences at the Georg-August University, Justus von Liebig Weg 11, 37077 Göttingen, Germany
}

Received 20 March 2007; accepted in revised form 13 September 2007; available online 26 September 2007

\begin{abstract}
Iron is limiting phytoplankton productivity in large parts of today's oceans, the so-called HNLC (high nutrient low chlorophyll) areas. It is a key component in photosynthesis during which inorganic carbon fixation in most phytoplankton species is sustained by so-called carbon concentrating mechanisms (CCMs). Here we investigate CCM regulation in the coccolithophore Emiliania huxleyi in response to varying degrees of iron limitation by means of membrane-inlet mass spectrometry. Compared to iron replete conditions rates of both active $\mathrm{CO}_{2}$ and $\mathrm{HCO}_{3}^{-}$uptake were markedly reduced under iron limitation leading to significantly diminished growth rates. Moreover, there was a concomitant decrease in CCM efficiency, reflected in an increased $\mathrm{CO}_{2}$ loss from the cell in relation to carbon fixation. Under such conditions higher values for carbon isotope fractionation $\left(\epsilon_{\mathrm{p}}\right)$ would be expected. However, direct measurements of $\epsilon_{\mathrm{p}}$ showed that carbon isotope fractionation was insensitive to changes in growth rates and CCM activity. This can be explained by concomitant changes in internal DIC fluxes in and out of the chloroplast as demonstrated with a simple cell model comprising two compartments. Thus, carbon isotope fractionation reflects the ability of phytoplankton to actively control their inorganic carbon acquisition depending on environmental conditions. The insensitivity of carbon isotope fractionation to changes in the availability of iron could be of interest for paleoreconstructions in the HNLC areas of today's oceans.
\end{abstract}

(C) 2007 Elsevier Ltd. All rights reserved.

\section{INTRODUCTION}

In large parts of the ocean, the so-called High Nutrients Low Chlorophyll (HNLC) areas, phytoplankton growth is limited by the availability of iron (de Baar and Boyd, 2000). The inability of phytoplankton to completely utilize the available major nutrients stems from the essential role of iron in photosynthesis, where it is an integral part of photo-

\footnotetext{
* Corresponding author. Fax: +49 4316004469.

E-mail address: kschulz@ifm-geomar.de (K.G. Schulz).
}

systems I and II (PSI and PSII, respectively) and various cytochromes of the photosynthetic electron transport chain (Greene et al., 1991; Greene et al., 1992). Additionally, iron limitation induces chlorosis, reduced levels of chlorophyll concentration in chloroplasts. Together, this results in reduced rates of photosynthesis (Greene et al., 1991), hence cellular growth rates of marine phytoplankton.

Most of the photosynthetically generated reductive power (i.e. NADPH) and energy (i.e. ATP) is used to reduce and assimilate inorganic carbon (Falkowski and Raven, 1997). In most species a large proportion of these energetic costs are associated with the operation of 
so-called carbon concentrating mechanisms (CCMs) to increase $\mathrm{CO}_{2}$ concentrations at the site of carboxylation (Raven and Lucas, 1985; Badger et al., 1998; Thoms et al., 2001). The reason for employing such energy consuming processes, such as active uptake of $\mathrm{CO}_{2}$ and/or $\mathrm{HCO}_{3}^{-}$, rests on the comparatively low affinity of the main carboxylating enzyme RubisCO (Ribulose-1,5-bisphosphate carboxylase/ oxygenase) for its substrate $\mathrm{CO}_{2}$, a slow maximum turnover rate and its susceptibility for a competing reaction with $\mathrm{O}_{2}$ (Badger et al., 1998). Thus, increasing $\left[\mathrm{CO}_{2}\right]$ at the site of RubisCO activity allows for higher carbon fixation, a prerequisite for high growth rates.

The CCM activity is influenced by various abiotic factors such as $\left[\mathrm{CO}_{2}\right]$ (Burkhardt et al., 2001; Rost et al., 2003), light (Beardall, 1991; Rost et al., 2006) and temperature (Davison, 1987). This active CCM regulation allows phytoplankton to optimize their energy and resource allocation. Finally, CCM activity is reflected in the carbon isotopic composition of the organic matter produced during photosynthesis, depending on the ratio of $\mathrm{CO}_{2}$ to $\mathrm{HCO}_{3}^{-}$utilized and the portion of inorganic carbon taken up which is not fixed by RubisCO but escapes the cell, termed leakage (e.g. Sharkey and Berry, 1985; Laws et al., 2002; Raven et al., 2002).

Here we investigate the role of iron availability for inorganic carbon acquisition, certain parameters of CCM activity and stable carbon isotope fractionation in the coccolithophore Emiliania huxleyi.

\section{METHODS}

\subsection{Experimental setup}

Mono-specific cultures of Emiliania huxleyi clone PML B92/11 were grown in duplicate at $15^{\circ} \mathrm{C}$ in $0.2 \mu \mathrm{m}$ filtered Antarctic seawater (salinity of 31 ) at a photon flux density (PFD) of $180 \mu \mathrm{mol} \mathrm{m} \mathrm{m}^{-2} \mathrm{~s}^{-1}$, supplied from cool white fluorescent bulbs (Philips TLD 36W/54) on a 16/8 light/dark cycle. The growth medium was enriched with nitrate and phosphate (64 and $4 \mu \mathrm{mol} \mathrm{kg}{ }^{-1}$, respectively), the vitamins $\mathrm{B} 12$, biotine and thiamine- $\mathrm{HCl}\left(0.59,9.2\right.$ and $59 \mathrm{nmol} \mathrm{kg}^{-1}$, respectively) and a metal mix (excluding iron) as described in Schulz et al. (2004). Final [Fe(III)'] (total dissolved inorganic iron(III) species) were adjusted by addition of $1.2 \mathrm{mmol} \mathrm{kg}^{-1}$ of $\mathrm{Na}_{2}$ EDTA $\cdot 6 \mathrm{H}_{2} \mathrm{O}$ and varying amounts of $\mathrm{FeCl}_{3}(2000,8$ and $0 \mathrm{nmol} \mathrm{kg}{ }^{-1}$, referred to hereafter as iron replete, intermediate and deplete) to the media, which after adjustment to a $\mathrm{pH}_{\mathrm{F}}(\mathrm{pH}$ determined on the free scale) of about 8.0 with $\mathrm{NaOH}$ was stored for $24 \mathrm{~h}$ in the dark to allow chemical equilibration. Precultures and experimental incubations in dilute batch cultures ensured exponential growth throughout the experiment (final concentrations lower than 30,000 cells per milliliter). Investigation of photosynthetic oxygen evolution and inorganic carbon fluxes were performed in a thermostated cuvette attached to a sectorfield multicollector mass spectrometer (Isoprime; GV Instruments, England) via a gas permeable membrane $(0.01 \mathrm{~mm}$ PTFE) inlet system at an incident PFD of $300 \mu \mathrm{mol} \mathrm{m} \mathrm{m}^{-2} \mathrm{~s}^{-1}$.

For inorganic carbon and oxygen flux determinations at the end of incubations (see next section for details), cells were concentrated about $100-500$ times by centrifugation at $450 \mathrm{~g}$ for $10 \mathrm{~min}$ at $15^{\circ} \mathrm{C}$. After these measurements, subsamples were taken for chlorophyll $a(\mathrm{Chl} a)$ determination and cell counts. Chl $a$ was measured spectrophotometrically as described by Strickland and Parsons (1968). Cell counts were obtained on a BD FacsCalibur flowcytometer and specific growth rates calculated from counts taken at the beginning and end of incubations.

\subsection{Photosynthesis and inorganic carbon flux determinations}

Investigation of photosynthetic oxygen evolution and inorganic carbon fluxes during steady-state photosynthesis followed the method and equations described by Badger et al. (1994) with some modifications outlined below. It is based on simultaneous measurement of $\left[\mathrm{CO}_{2}\right]$ and $\left[\mathrm{O}_{2}\right]$ during consecutive light $(7 \mathrm{~min})$ and dark $(7 \mathrm{~min})$ cycles at increasing dissolved inorganic carbon (DIC) concentrations in an initially DIC-free assay buffer, i.e. seawater buffered with $50 \mathrm{mM}$ 4-(2-hydroxyethyl)-1-piperazineethanesulfonic acid (HEPES) at $\mathrm{pH}_{\mathrm{T}} \sim 7.9$ at $15.5^{\circ} \mathrm{C}$ which had been bubbled with $\mathrm{CO}_{2}$-free air. The offset between $\mathrm{pH}$ on the free scale $\left(\mathrm{pH}_{\mathrm{F}}\right)$ and the total scale $\left(\mathrm{pH}_{\mathrm{T}}\right)$ is about $0.1 \mathrm{pH}$ units (Zeebe and Wolf-Gladrow, 2001). The membrane inlet mass spectrometer (MIMS) was calibrated for $\mathrm{CO}_{2}$ by injections of known amounts of $\mathrm{NaH}^{12} \mathrm{CO}_{3}$ and $\mathrm{NaH}^{12} \mathrm{CO}_{3}$ into $8 \mathrm{ml}$ of $0.2 \mathrm{M} \mathrm{HCl}$ (from here on, carbon species without ${ }^{13} \mathrm{C}$ or ${ }^{12} \mathrm{C}$ notation will refer to the sum of both). The $\mathrm{CO}_{2}$ baseline was determined by addition of $20 \mu \mathrm{l} 10 \mathrm{M}$ $\mathrm{NaOH}$. Calibration for $\mathrm{O}_{2}$ was achieved by measuring an oxygen-free and an air-saturated $\left(21 \% \mathrm{O}_{2}\right)$ assay buffer sample for which $\left[\mathrm{O}_{2}\right]$ was calculated according to Garcia and Gordon (1992). The measured $\left[\mathrm{O}_{2}\right]$ was corrected for the $\mathrm{O}_{2}$ consumption of the MIMS which was determined by following the oxygen evolution in an initially air-saturated assay buffer for approximately $1 \mathrm{~h}$ and deriving a linear relation between $\left[\mathrm{O}_{2}\right]$ and $\mathrm{d}\left[\mathrm{O}_{2}\right] / \mathrm{d} t$. In contrast, $\mathrm{CO}_{2}$ consumption was negligible. The simultaneously recorded argon signal, which is not affected by biological activities, was used to correct for periodical signal fluctuations in the oxygen, and in some cases, the carbon dioxide recordings.

Uptake of $\mathrm{CO}_{2}$ and $\mathrm{HCO}_{3}^{-}$by active transport and $\mathrm{CO}_{2}$ fluxes by passive diffusion during steady-state photosynthesis were deduced from measurements of $\mathrm{O}_{2}$ and $\mathrm{CO}_{2}$ evolution during consecutive dark/light cycles (Fig. 1) at increasing [DIC] $\left(\mathrm{NaHCO}_{3}\right.$ additions), making use of the chemical disequilibrium in the carbonate system created during photosynthesis. For that purpose, the cells were incubated in the assay buffer in the presence of an inhibitor for extracellular carbonic anhydrase (dextran-bound sulfonamide, DBS). This blocks the otherwise rapid inter-conversion between $\mathrm{CO}_{2}$ and $\mathrm{HCO}_{3}^{-}$mediated by $\mathrm{CA}$ and allows establishment of a chemical disequilibrium (Fig. 2).

\subsubsection{Flux calculations}

In the following the calculations of the active $\mathrm{CO}_{2}$ and $\mathrm{HCO}_{3}^{-}$uptake rates and the $\mathrm{CO}_{2}$ flux rates into and out of a cell by passive diffusion are described (for a graphical representation of the corresponding fluxes see Fig. 2). For each of the consecutive dark/light cycles at increasing [DIC] calculations of net carbon fixation rates (including 




Fig. 1. Example of $\mathrm{O}_{2}$ (a) and $\mathrm{CO}_{2}$ (b) evolution of Emiliania huxleyi measured during a consecutive dark/light cycle. The $\mathrm{O}_{2}$ evolution at the end of the dark period $\left(\left.\frac{\mathrm{d}\left[\mathrm{O}_{2}\right]}{\mathrm{d} t}\right|_{D 1}\right)$ depicts the respiration rate in the dark, $\left.\frac{\mathrm{d}\left[\mathrm{O}_{2}\right]}{\mathrm{d} t}\right|_{\mathrm{EL}}$ the net fixation rate, and $\left[\mathrm{O}_{2}\right]_{\mathrm{BL}}$ and $\left[\mathrm{O}_{2}\right]_{\mathrm{EL}}$ the oxygen concentrations at the end of dark and light phase, respectively. When accounting for the chemical disequilibrium in the carbonate system, the $\mathrm{CO}_{2}$ evolution at the end of the dark period $\left(\left.\frac{\mathrm{d}\left[\mathrm{CO}_{2}\right]}{\mathrm{d} t}\right|_{D 1}\right)$ equally describes the respiration rate in the dark, as does the simultaneous oxygen evolution. $\left.\frac{\mathrm{d}\left[\mathrm{CO}_{2}\right]}{\mathrm{d} t}\right|_{\mathrm{EL}}$ describes the net $\mathrm{CO}_{2}$ uptake and $\left.\frac{\mathrm{d}\left[\mathrm{CO}_{2}\right]}{\mathrm{d} t}\right|_{D 2}$ the $\mathrm{CO}_{2}$ efflux rate. $\left[\mathrm{CO}_{2}\right]_{\mathrm{BL}}$ and $\left[\mathrm{CO}_{2}\right]_{\mathrm{EL}}$ depict the carbon dioxide concentrations at the end of the dark and light period, respectively.

respiration), respiration rates in the dark (in terms of carbon) and the total amount of carbon fixed follow as

$\mathrm{NetFix}_{\text {rate }}=\left.\frac{\mathrm{d}\left[\mathrm{O}_{2}\right]}{\mathrm{d} t}\right|_{\mathrm{EL}} / \mathrm{PQ}$

with PQ being the photosynthetic quotient assumed to be 1.4 as predicted for phytoplankton growth on nitrate (Laws, 1991) and $\left.\frac{\mathrm{d}\left[\mathrm{O}_{2}\right]}{\mathrm{d} t}\right|_{\mathrm{EL}}$ the temporal oxygen evolution at the end of the light phase (Fig. 1). Respiration rates in the dark are

$\operatorname{Resp}_{\text {rate }}=-\left.\frac{\mathrm{d}\left[\mathrm{O}_{2}\right]}{\mathrm{d} t}\right|_{D 1} / \mathrm{RQ}$

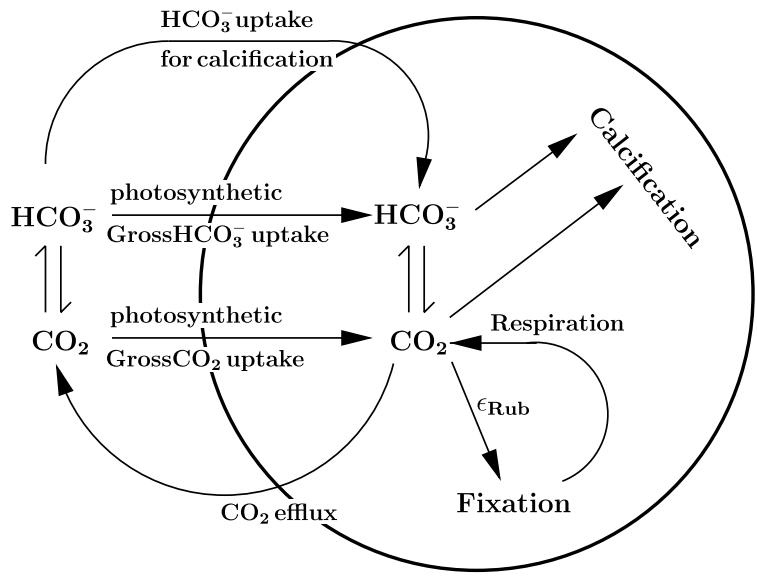

Fig. 2. Carbon fluxes as detectable with the approach described in the Section 2. $\epsilon_{\mathrm{Rub}}$ illustrates carbon isotope fractionation of RubisCO associated with photosynthetic $\mathrm{CO}_{2}$ fixation. Note that the photosynthetic gross $\mathrm{CO}_{2}$ uptake includes both active and diffusive fluxes while the $\mathrm{CO}_{2}$ efflux is driven by passive diffusion only.

with RQ being the respiratory quotient (assumed to be 1). The term $\left.\frac{\mathrm{d}\left[\mathrm{O}_{2}\right]}{\mathrm{d} t}\right|_{D 1}$ denotes the temporal oxygen evolution at the end of the dark (Fig. 1). The difference in oxygen concentrations before and at the end of a light period $\left(\Delta\left[\mathrm{O}_{2}\right]\right)$ corresponds to the amount of net inorganic carbon fixation during that respective period of time $(\mathrm{t})$ as

$\operatorname{NetFix}_{\text {amount }}=\left(\Delta\left[\mathrm{O}_{2}\right]\right) / \mathrm{PQ}$

To determine net $\mathrm{CO}_{2}$ uptake rates, it is necessary to account for the chemical disequilibrium in the carbonate system caused by the inorganic carbon uptake and release during photosynthesis and respiration, respectively. For that purpose, $\left[\mathrm{CO}_{2}\right]$ and $\left[\mathrm{HCO}_{3}^{-}\right]$at the end of the light phase have to be known. However, of all three carbon species, only $\mathrm{CO}_{2}$ can be monitored with the MIMS. Accordingly, Badger et al. (1994) deduced $\left[\mathrm{HCO}_{3}^{-}\right]_{\mathrm{EL}}$ in the following manner. The respiration rate in the dark, calculated according to Eq. (2), can equally be expressed in terms of the temporal change in $\left[\mathrm{CO}_{2}\right]$ in the dark when accounting for the chemical disequilibrium as

$\operatorname{Resp}_{\text {rate }}=\left.\frac{\mathrm{d}\left[\mathrm{CO}_{2}\right]}{\mathrm{d} t}\right|_{D 1}+k_{+}\left[\mathrm{CO}_{2}\right]_{\mathrm{BL}}-k_{-}\left[\mathrm{HCO}_{3}^{-}\right]_{\mathrm{BL}}$

with $k_{+}$and $k_{-}$being the rate constants for the $\mathrm{CO}_{2}$ to $\mathrm{HCO}_{3}^{-}$inter-conversion, calculated according to Schulz et al. (2006). The term $\left.\frac{\mathrm{d}\left[\mathrm{CO}_{2}\right]}{\mathrm{d} t}\right|_{D 1}$ denotes the temporal $\mathrm{CO}_{2}$ evolution at the end of the dark phase before switching on the light, and $\left[\mathrm{CO}_{2}\right]_{\mathrm{BL}}$ and $\left[\mathrm{HCO}_{3}^{-}\right]_{\mathrm{BL}}$ the respective $\left[\mathrm{CO}_{2}\right]$ and $\left[\mathrm{HCO}_{3}^{-}\right]$before this light phase (Fig. 1). Solving for $\left[\mathrm{HCO}_{3}^{-}\right]_{\mathrm{BL}}$ yields

$\left[\mathrm{HCO}_{3}^{-}\right]_{\mathrm{BL}}=\left(\left.\frac{\mathrm{d}\left[\mathrm{CO}_{2}\right]}{\mathrm{d} t}\right|_{D 1}+k_{+}\left[\mathrm{CO}_{2}\right]_{\mathrm{BL}}-\operatorname{Resp}_{\text {rate }}\right) / k_{-}$

Having established $\left[\mathrm{HCO}_{3}^{-}\right]_{\mathrm{BL}},\left[\mathrm{HCO}_{3}^{-}\right]_{\mathrm{EL}}$ is deduced in a stepwise manner starting with the calculation of [DIC] before the light where at constant $\mathrm{pH}$ the unknown $\left[\mathrm{CO}_{3}^{2-}\right]_{\mathrm{BL}}$ is described as a constant fraction of the DIC pool, with $f=\left[\mathrm{CO}_{3}^{2-}\right] /\left[\mathrm{HCO}_{3}^{-}\right]$. This is justified as there is 
no chemical disequilibrium between $\mathrm{HCO}_{3}^{-}$and $\mathrm{CO}_{3}^{2-}$ on the timescale of seconds, owing to the relatively rapid inter-conversion rates between them. The factor $\mathrm{f}$ was determined together with the $\mathrm{CO}_{2}$ calibration of the MIMS (for details see Schulz et al., 2006). It involves calculation of the carbonate system from the ratio of known additions of DIC to measured $\mathrm{CO}_{2}$ in the assay buffer using the dissociation constants of Mehrbach et al. (1973) as refitted by Dickson and Millero (1987). [DIC] before the light period is then given as

$[\mathrm{DIC}]_{\mathrm{BL}}=\left[\mathrm{CO}_{2}\right]_{\mathrm{BL}}+(1+f)\left[\mathrm{HCO}_{3}^{-}\right]_{\mathrm{BL}}$

It follows that the [DIC] at the end of the light period is then determined by $[\mathrm{DIC}]_{\mathrm{BL}}$ and the amount of net inorganic carbon fixation during photosynthesis:

$[\mathrm{DIC}]_{\mathrm{EL}}=[\mathrm{DIC}]_{\mathrm{BL}}-\mathrm{NetFix}_{\text {amount }}$

Finally, the $\left[\mathrm{HCO}_{3}^{-}\right]$at the end of the light period is given by

$\left[\mathrm{HCO}_{3}^{-}\right]_{\mathrm{EL}}=\left([\mathrm{DIC}]_{\mathrm{EL}}-\left[\mathrm{CO}_{2}\right]_{\mathrm{EL}}\right) /(1+f)$

Having derived $\left[\mathrm{HCO}_{3}^{-}\right]_{\mathrm{EL}}$ allows calculation of the net $\mathrm{CO}_{2}$ uptake rate as

$$
\begin{aligned}
\mathrm{NetCO}_{2} \mathrm{up}_{\text {rate }}= & -\left.\frac{\mathrm{d}\left[\mathrm{CO}_{2}\right]}{\mathrm{d} t}\right|_{\mathrm{EL}}+k_{-}\left[\mathrm{HCO}_{3}^{-}\right]_{\mathrm{EL}} \\
& -k_{+}\left[\mathrm{CO}_{2}\right]_{\mathrm{EL}}
\end{aligned}
$$

with $-\left.\frac{\mathrm{d}\left[\mathrm{CO}_{2}\right]}{\mathrm{d} t}\right|_{\mathrm{EL}}$ being the temporal $\mathrm{CO}_{2}$ evolution at the end of the light phase. Two processes are driving this net $\mathrm{CO}_{2}$ uptake into the cytosol, passive diffusion and active transport. Hence, net $\mathrm{CO}_{2}$ uptake can also be written as

$$
\begin{aligned}
\mathrm{NetCO}_{2} \text { up }_{\text {rate }}= & P \times A \times\left(\left[\mathrm{CO}_{2}\right]_{\mathrm{ext}}-\left[\mathrm{CO}_{2}\right]_{\mathrm{cyt}}\right) \\
& + \text { ActiveCO} \\
& \mathrm{up}_{\text {rate }}
\end{aligned}
$$

where $P$ denotes the plasmamembrane permeability for $\mathrm{CO}_{2}$ (given in $\mathrm{m} \mathrm{s}^{-1}$ ), $A$ the surface area of the cell, defined as $A=4 \pi \mathrm{r}^{2}$ (given in $\mathrm{m}^{2}$ ), and $\left[\mathrm{CO}_{2}\right]_{\mathrm{ext}}$ and $\left[\mathrm{CO}_{2}\right]_{\text {cyt }}$ the concentrations of $\mathrm{CO}_{2}$ in the external medium and in the cytosol, respectively (given in $\mathrm{mol} \mathrm{m}^{-3}$ ). Note that $\left[\mathrm{CO}_{2}\right]_{\text {ext }}$ and $\left[\mathrm{CO}_{2}\right]_{\mathrm{EL}}$ are the same. The net flux of $\mathrm{CO}_{2}$ by passive diffusion is proportional to the $\mathrm{CO}_{2}$ difference (gradient) between the external medium and the cytosol. It is directed into the cell if external $\left[\mathrm{CO}_{2}\right]$ are higher than in the cytosol and outside the cell if the gradient is reversed.

The portion of net carbon fixation which can not be explained by $\mathrm{CO}_{2}$ uptake must then have other inorganic carbon sources. Assuming that $\mathrm{CO}_{2}$ and $\mathrm{HCO}_{3}^{-}$are the only inorganic carbon species taken up for photosynthesis by phytoplankton cells, net $\mathrm{HCO}_{3}^{-}$uptake rates are then given as the difference between net carbon fixation and net $\mathrm{CO}_{2}$ uptake as

$\mathrm{NetHCO}_{3}^{-}$up $_{\text {rate }}=\mathrm{NetFix}_{\text {rate }}-\mathrm{NetCO}_{2}$ up $_{\text {rate }}$

Provided that inorganic carbon can leak out of phytoplankton cells only as $\mathrm{CO}_{2}$ and not in the ionic forms it follows that net equals gross $\mathrm{HCO}_{3}^{-}$uptake (note that the uptake of $\mathrm{HCO}_{3}^{-}$by diffusion is restricted by the low solubility of charged molecules in membrane lipids and by the insidenegative electric potential difference across the plasma- lemma in marine autotrophs (Raven, 1980, 1997)). In coccolithophores the total uptake of $\mathrm{HCO}_{3}^{-}$is actually higher than calculated above as inorganic carbon is also utilized in calcification (for details see Section 2.2.2).

Uptake of $\mathrm{CO}_{2}$ by active transport into the cell is estimated from the temporal $\mathrm{CO}_{2}$ evolution right after switching off the light, $\left.\frac{\mathrm{d}\left[\mathrm{CO}_{2}\right]}{\mathrm{dt}}\right|_{\mathrm{D} 2}$ (Fig. 1). Accounting for the chemical disequilibrium in the carbonate system and assuming that inorganic carbon uptake and fixation ceases immediately without the supply of light, net $\mathrm{CO}_{2}$ efflux rates are given by

$$
\begin{aligned}
\mathrm{NetCO}_{2} \mathrm{eff}_{\text {rate }}= & \left.\frac{\mathrm{d}\left[\mathrm{CO}_{2}\right]}{\mathrm{d} t}\right|_{\mathrm{D} 2}-k_{-}\left[\mathrm{HCO}_{3}^{-}\right]_{\mathrm{EL}} \\
& +k_{+}\left[\mathrm{CO}_{2}\right]_{\mathrm{EL}}
\end{aligned}
$$

In analogy to the net $\mathrm{CO}_{2}$ uptake under steady state conditions in the light Eq. (10), the net $\mathrm{CO}_{2}$ efflux by diffusion in the dark, right after switching of the light, is given as

$\mathrm{NetCO}_{2} \mathrm{eff}_{\text {rate }}=-P \times A \times\left(\left[\mathrm{CO}_{2}\right]_{\mathrm{ext}}-\left[\mathrm{CO}_{2}\right]_{\mathrm{cyt}}\right)$

Note that this calculated net $\mathrm{CO}_{2}$ efflux is most likely smaller than the true one, because initial slopes in general and this in one particular tend to be underestimates (for details see Badger et al., 1994; Schulz et al., 2006). Combining net $\mathrm{CO}_{2}$ uptake Eq. (10) and net $\mathrm{CO}_{2}$ efflux Eq. (13) gives the $\mathrm{CO}_{2}$ uptake by active transport with

ActiveCO $\mathrm{Cp}_{\text {rate }}=\mathrm{NetCO}_{2}$ up $_{\text {rate }}+\mathrm{NetCO}_{2}$ eff rate

Gross DIC uptake rates into the cell are then given by the sum of active $\mathrm{CO}_{2}$ and $\mathrm{HCO}_{3}^{-}$uptake and passive $\mathrm{CO}_{2}$ diffusion as

$$
\begin{aligned}
\text { DICup }_{\text {rate }}= & \text { Gross } \mathrm{HCO}_{3}^{-} \text {up }_{\text {rate }}+\text { ActiveCO }_{2} \text { up }_{\text {rate }} \\
& +\operatorname{diffCO}_{2} \text { up }_{\text {rate }}
\end{aligned}
$$

with diffCO up $_{\text {rate }}=P \times A \times\left[\mathrm{CO}_{2}\right]_{\text {ext }}$. Analogously, gross $\mathrm{CO}_{2}$ efflux by passive diffusion is given by diffCO $\mathrm{Off}_{\text {rate }}=$ $P \times A \times\left[\mathrm{CO}_{2}\right]_{\mathrm{cyt}}$, with $\left[\mathrm{CO}_{2}\right]_{\mathrm{cyt}}$ derived from Eq. (13). Then, the proportion of inorganic carbon taken up which escapes fixation is given by the so-called leakage (Sharkey and Berry, 1985) as

Leakage $=\frac{\text { diffCO }_{2} \text { eff }_{\text {rate }}}{\text { DICup }_{\text {rate }}}$

\subsubsection{Uptake of inorganic carbon for $\mathrm{CaCO}_{3}$ production}

If calcifying organisms such as coccolithophores are investigated, Eq. (7) can be extended to account for the light-dependent inorganic carbon uptake fueling calcification. Application of the particulate inorganic carbon (PIC) to particulate organic carbon (POC) ratio allows to express calcification in terms of net carbon fixation during photosynthesis. However, while the amount of PIC produced in the light remains unaltered in the dark phase, some of the POC will be respired. Therefore, measured PIC/POC ratios, $\left.\frac{\mathrm{PIC}}{\mathrm{POC}}\right|_{\mathrm{M}}$ (see end of Section 2.3 for details), have to be corrected for respiratory loss of POC in the dark. Given a 16/8 hour light/dark cycle, the PIC to POC production rate in the light is therefore

$\left.\frac{\mathrm{PIC}}{\mathrm{POC}}\right|_{\mathrm{L}}=\frac{16 \mathrm{NetFix}_{\text {rate }}-8 \mathrm{Resp}_{\text {rate }}}{16 \mathrm{NetFix}_{\text {rate }}} \times\left.\frac{\mathrm{PIC}}{\mathrm{POC}}\right|_{\mathrm{M}}$ 
Calculated values for PIC/POC ratios in the light, $\left.\frac{\mathrm{PIC}}{\mathrm{POC}}\right|_{\mathrm{L}}$, were $0.48,0.43$ and 0.38 for iron replete, intermediate and deplete conditions, respectively. Hence, it follows that the amount of dissolved inorganic carbon utilized in calcification during the light is given by

Calcification $_{\text {amount }}=$ NetFix $_{\text {amount }} \times\left.\frac{\mathrm{PIC}}{\mathrm{POC}}\right|_{\mathrm{L}}$

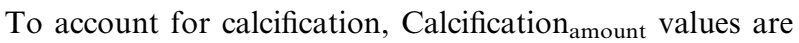
then subtracted from [DIC $]_{\mathrm{EL}}$ in Eq. (7).

\subsubsection{Final remarks on the assessment of inorganic carbon fluxes}

In summary, the calculations presented here differ in a number of aspects from those desribed by Badger et al. (1994): the explicit inclusion of $\mathrm{CO}_{3}^{2-}$, the incorporation of calcification and the assessment of gross $\mathrm{CO}_{2}$ fluxes by considering passive diffusion. The latter is a prerequisite when relating cellular inorganic carbon fluxes to stable carbon isotope fractionation.

\subsection{Carbon isotope fractionation}

In a second experimental approach E. huxleyi was grown in duplicate under varying $\left[\mathrm{Fe}(\mathrm{III})^{\prime}\right]$ (with the same dilute batch culture setup used for the investigation of inorganic carbon fluxes) and stable carbon isotope fractionation was investigated. The carbonate system of the culture media was calculated from $\mathrm{pH}$ and total dissolved inorganic carbon (DIC) using the dissociation constants of Mehrbach et al. (1973) as refitted by Dickson and Millero (1987). The $\mathrm{pH}$ was measured following the procedure described by DOE (1994) and the DIC concentration was determined using a photochemical approach (Stoll et al., 2001).

For analysis of the stable carbon isotope composition of POC, duplicate subsamples of the incubations were filtered on precombusted $\left(500^{\circ} \mathrm{C}\right)$ Whatman $\mathrm{GF} / \mathrm{F}$ filters and stored at $-25^{\circ} \mathrm{C}$. Prior to analysis the POC filters were fumed with concentrated $\mathrm{HCl}$ and analyzed on an ANCA-SL 20-20 Europa Scientific mass spectrometer after $2 \mathrm{~h}$ of drying at $60^{\circ} \mathrm{C}$. The isotopic composition is reported relative to a standard (Vienna PeeDee belemnite, V-PDB) as

$\delta^{13} \mathrm{C}_{\text {sample }}=\left[\frac{\left({ }^{13} \mathrm{C} /{ }^{12} \mathrm{C}\right)_{\text {sample }}}{\left({ }^{13} \mathrm{C} /{ }^{12} \mathrm{C}\right)_{\mathrm{PDB}}}-1\right] \times 1000$

The carbon isotope fractionation associated with POC production $\left(\epsilon_{\mathrm{p}}\right)$ was calculated relative to the isotopic composition of $\mathrm{CO}_{2}$ in the medium as

$\epsilon_{\mathrm{p}}=\left(\frac{\delta^{13} \mathrm{C}_{\mathrm{CO}_{2}}+1000}{\delta^{13} \mathrm{C}_{\mathrm{POC}}+1000}-1\right) \times 1000$

where $\delta^{13} \mathrm{C}_{\mathrm{CO}_{2}}$ was calculated from the isotopic composition of the DIC pool $\left(\delta^{13} \mathrm{C}_{\mathrm{DIC}}\right)$ (Zeebe and Wolf-Gladrow, 2001) making use of the temperature-dependent fractionation factors between $\mathrm{CO}_{2}$ and $\mathrm{HCO}_{3}^{-}\left(\epsilon_{\mathrm{db}}\right)$, and $\mathrm{HCO}_{3}^{-}$ and $\mathrm{CO}_{3}^{2-}\left(\epsilon_{\mathrm{cb}}\right)$ given by Mook (1986) and Zhang et al. (1995), respectively $\delta^{13} \mathrm{C}_{\mathrm{CO}_{2}}=\delta^{13} \mathrm{C}_{\mathrm{HCO}_{3}^{-}} \times\left(1+\epsilon_{\mathrm{db}} \times 10^{-3}\right)+\epsilon_{\mathrm{db}}$

with

$\delta^{13} \mathrm{C}_{\mathrm{HCO}_{3}^{-}}$

$=\frac{\delta^{13} \mathrm{C}_{\mathrm{DIC}}[\mathrm{DIC}]-\left(\epsilon_{\mathrm{db}}\left[\mathrm{CO}_{2}\right]+\epsilon_{\mathrm{cb}}\left[\mathrm{CO}_{3}^{2-}\right]\right)}{\left(1+\epsilon_{\mathrm{db}} \times 10^{-3}\right)\left[\mathrm{CO}_{2}\right]+\left[\mathrm{HCO}_{3}^{-}\right]+\left(1+\epsilon_{\mathrm{cb}} \times 10^{-3}\right)\left[\mathrm{CO}_{3}^{2-}\right]}$

For determination of the isotopic composition of the DIC pool ( $\left.\delta^{13} \mathrm{DIC}\right), 8 \mathrm{ml}$ of $0.2 \mu \mathrm{m}$ filtered subsamples were fixed with $\mathrm{HgCl}_{2}$ (final concentration $\sim 150 \mathrm{mg} \mathrm{kg}^{-1}$ ) which were analyzed in the laboratory of $\mathrm{H}$. Spero, University of California Davis.

The relationship between stable carbon isotope fractionation and inorganic carbon fluxes has been described by Farquhar et al. (1982) and Sharkey and Berry (1985) (for a graphical representation see Fig. 2). The two key variables are the so-called leakage, defined as the ratio of the $\mathrm{CO}_{2}$ efflux to the total inorganic carbon uptake (Eq. (16)) and the isotopic composition of the inorganic carbon source.

$\epsilon_{\mathrm{p}}=a \epsilon_{\mathrm{db}}+\epsilon_{\mathrm{Rub}} \frac{\text { diffCO }_{2} \text { eff }}{\text { DICup }}$

where $\epsilon_{\mathrm{Rub}}$ denotes the kinetic fractionation of RubisCO, which is approximately 29\%o (Roeske and O'Leary, 1984). Introduced by Burkhardt et al. (1999), the factor $a$ describes the contribution of $\mathrm{HCO}_{3}^{-}$to the total DIC uptake and $\epsilon_{\mathrm{db}}$ the equilibrium fractionation between the two carbon sources $\mathrm{CO}_{2}$ and $\mathrm{HCO}_{3}^{-}$. The smaller the fixation flux in relation to the inorganic carbon uptake flux the bigger the leakage and hence $\epsilon_{\mathrm{p}}$. However, implicit in this model are the assumptions that (1) the cell consists only of a single compartment, (2) there is no fractionation associated with respiration, and (3) DIC can leak out of the cell only as $\mathrm{CO}_{2}$ and not in the form of $\mathrm{HCO}_{3}^{-}$.

Additionally, in this second experimental approach PIC was determined as the difference between total particulate carbon (TPC) and POC, yielding PIC/POC. The measurements of TPC followed those for POC except that the filters were not fumed with concentrated $\mathrm{HCl}$.

\subsection{Data fitting procedures}

Kinetic parameters such as $V_{\max }$ and $K_{1 / 2}$ of active $\mathrm{CO}_{2}$ and $\mathrm{HCO}_{3}^{-}$uptake (see Table 1) were obtained from a Michaelis-Menten fit to the combined data of independent measurements of the form

$V=V_{\max } \frac{[\mathrm{S}]}{[\mathrm{S}]+K_{1 / 2}}$

where $V$ denotes the actual uptake rate, $V_{\max }$ the maximum uptake rate, $[\mathrm{S}]$ the actual substrate $\left(\mathrm{CO}_{2}\right.$ or $\left.\mathrm{HCO}_{3}^{-}\right)$concentration and $K_{1 / 2}$ the substrate concentration at which the uptake rate is half its maximum value.

Kinetic parameters such as $V_{\max }$ and $K_{1 / 2}$, of net fixation in terms of $\mathrm{CO}_{2}$ and $\mathrm{HCO}_{3}^{-}$(see Table 1) were obtained from a modified Michaelis-Menten fit (compare Buitenhuis et al. (2003)) to the combined data of independent measurements of the form 
Table 1

$V_{\text {max }}$ and $K_{1 / 2}$ values for net $\mathrm{CO}_{2}$ fixation, active $\mathrm{CO}_{2}$ and $\mathrm{HCO}_{3}^{-}$uptake, specific growth rates and cellular chlorophyll $a$ content of Emiliania huxleyi cultured under iron replete, intermediate and deplete conditions

\begin{tabular}{|c|c|c|c|c|c|c|}
\hline \multirow[t]{2}{*}[\mathrm{Fe}(\mathrm{III})^{\prime}]{} & \multirow[t]{2}{*}{ Growth $(\mu)$} & \multirow[t]{2}{*}{ Chl $a /$ cell } & \multicolumn{4}{|l|}{ Net fixation } \\
\hline & & & $V_{\max }\left(\mathrm{CO}_{2}\right)$ & $K_{1 / 2}\left(\mathrm{CO}_{2}\right)$ & $V_{\max }\left(\mathrm{HCO}_{3}^{-}\right)$ & $K_{1 / 2}\left(\mathrm{HCO}_{3}^{-}\right)$ \\
\hline Replete & $0.86 \pm 0.01$ & $0.19 \pm 0.03$ & 0.052 & 5.6 & 0.051 & 365 \\
\hline Intermediate & $0.43 \pm 0.01$ & $0.05 \pm 0.01$ & 0.011 & 5.5 & 0.011 & 350 \\
\hline \multirow[t]{2}{*}{ Deplete } & $0.28 \pm 0.01$ & $0.02 \pm 0.01$ & 0.004 & 9.8 & 0.004 & 590 \\
\hline & & \multicolumn{2}{|l|}{ Active $\mathrm{CO}_{2}$ uptake } & & \multicolumn{2}{|l|}{$\mathrm{HCO}_{3}^{-}$uptake } \\
\hline Replete & & 0.052 & 3.9 & & 0.030 & 871 \\
\hline Intermediate & & 0.017 & 3.9 & & - & - \\
\hline Deplete & & 0.012 & 3.7 & & - & - \\
\hline
\end{tabular}

Kinetic parameters for active $\mathrm{CO}_{2}$ and $\mathrm{HCO}_{3}^{-}$uptake were obtained from a Michaelis-Menten fit to the combined data from independent measurements. Kinetic parameters for net fixation in terms of $\mathrm{CO}_{2}$ and $\mathrm{HCO}_{3}^{-}$were obtained from a modified Michaelis-Menten fit, allowing net fixation to be negative at substrate concentrations below the compensation point (see Section 2.4 for details). The $K_{1 / 2}$ values for intermediate and deplete iron conditions have to be taken with caution as no data points were below respective half-saturation concentrations. The resulting fitting curves are shown in Fig. 3. Values for $V_{\max }$ and $K_{1 / 2}$ are given in pmol cell ${ }^{-1} \mathrm{~h}^{-1}$ and $\mu \mathrm{mol} \mathrm{kg} \mathrm{g}^{-1}$, specific growth rates in divisions per day and chlorophyll $a$ per cell in pg, respectively.

$V=V_{\max } \frac{[\mathrm{S}]-\left[\mathrm{S}_{\min }\right]}{[\mathrm{S}]+K_{1 / 2}}$

where $V$ denotes the actual uptake rate, $V_{\max }$ the maximum uptake rate, $[\mathrm{S}]$ the actual substrate $\left(\mathrm{CO}_{2}\right.$ or $\left.\mathrm{HCO}_{3}^{-}\right)$concentration, $\left[\mathrm{S}_{\mathrm{min}}\right]$ the minimum substrate concentration for this particular reaction and $K_{1 / 2}$ the substrate concentration at which the rate is half its maximum value. This allows net carbon fixation to be negative at substrate concentrations below the compensation point when respiration exceeds photosynthesis.

Rates for active $\mathrm{CO}_{2}$ and $\mathrm{HCO}_{3}^{-}$uptake and net fixation at ambient seawater [DIC] of $2000 \mu \mathrm{mol} \mathrm{kg}^{-1}$ were derived from the fitted curves described above (compare Table 2). Corresponding rates for $\mathrm{CO}_{2}$ fluxes into and out of a cell by passive diffusion were calculated from linear fits to the

Table 2

Cellular inorganic carbon fluxes at ambient [DIC] of $2000 \mu \mathrm{mol}$ $\mathrm{kg}^{-1}$, derived from measurements and fits shown in Fig. 3 and 4 (see Section 2.4 for details), and parameters relevant for stable carbon isotope fractionation

\begin{tabular}{lccc}
\hline & {$\left[\mathrm{Fe}(\mathrm{III})^{\prime}\right]$} & & \\
\cline { 2 - 4 } & Replete & Intermediate & Deplete \\
\hline FIX & 0.046 & 0.010 & 0.003 \\
Active $\mathrm{HCO}_{3}^{-}$up & 0.020 & 0.005 & 0.003 \\
Active $_{2}$ up & 0.046 & 0.015 & 0.011 \\
ActiveDICup $_{\text {DiffCO }}$ up & 0.066 & 0.020 & 0.014 \\
DICup $_{\text {DiffCO }}$ eff & 0.152 & 0.155 & 0.160 \\
ActiveCO $_{2} /$ activeHCO & - & 0.174 \\
Active $^{-} \mathrm{HCO}_{3}^{-} / \mathrm{DICup}$ & 0.173 & 0.175 & 0.171 \\
Leakage & 0.09 & 0.33 & 0.37 \\
$\epsilon_{\mathrm{p}}(\%)$ (Eq. (23)) & 0.79 & 0.94 & 0.02 \\
DICup/FIX & 22.0 & 27.0 & 0.98 \\
Active DIC/FIX & 4.7 & 18.1 & 28.3 \\
\hline
\end{tabular}

Fluxes are given in pmol cell ${ }^{-1} \mathrm{~h}^{-1}$. respective data which were forced through zero, assuming no diffusion at external $\left[\mathrm{CO}_{2}\right]$ of zero (see Fig. 4).

\section{RESULTS}

Iron limitation significantly decreased growth rates, cellular $\mathrm{Chl} a$ concentrations, net photosynthetic $\mathrm{CO}_{2}$ fixation, as well as concomitant active $\mathrm{CO}_{2}$ and $\mathrm{HCO}_{3}^{-}$uptake rates (see Table 1 and Fig. 3). While maximum rates $\left(V_{\max }\right)$ for net $\mathrm{CO}_{2}$ fixation per cell were 10 times lower under iron limiting compared to iron-replete conditions, changes in corresponding half-saturation concentrations $\left(K_{1 / 2}\right)$ did not seem to follow a general trend. Similarly, $V_{\max }$ values for active $\mathrm{CO}_{2}$ uptake rates per cell declined about 5-fold from iron replete to iron deplete conditions while corresponding $K_{1 / 2}$ values appeared to be unaffected. However, it has to be kept in mind that $K_{1 / 2}$ values for intermediate and deplete iron conditions have to be taken with caution as no data points were below respective half-saturation concentrations (compare Fig. 3).

Respiration rates in the dark as well as net $\mathrm{CO}_{2}$ efflux were about twice as high under iron replete than deplete conditions (Fig. 3). In all iron treatments cytosolic $\left[\mathrm{CO}_{2}\right]$ were slightly higher than external ones, resulting in a slightly higher diffusive $\mathrm{CO}_{2}$ efflux than uptake (Fig. 4).

Calculated rates of net fixation and active $\mathrm{CO}_{2}$ and $\mathrm{HCO}_{3}^{-}$ uptake at ambient [DIC] of $2000 \mu \mathrm{mol} \mathrm{kg}{ }^{-1}$ were close to their respective $V_{\max }$ values (Table 2), yet not fully saturated. Thus, at [DIC] of $2000 \mu \mathrm{mol} \mathrm{kg} \mathrm{kg}^{-1}$ active DIC uptake of iron limited cells was about five times lower than that of 'unstressed' cultures. In contrast, uptake and efflux of $\mathrm{CO}_{2}$ by passive diffusion did not vary significantly (Table 2). Hence, leakage (the fraction of inorganic carbon taken up that escapes fixation and leaks out of the cell) increased from 0.79 under iron replete to 0.98 under iron deplete conditions. Also the proportion of $\mathrm{HCO}_{3}^{-}$to the overall DIC uptake declined from 0.09 to 0.02 (Table 2). According to Eq. (23) these results would predict stable carbon isotope fractionation with 



Fig. 3. Cellular rates of net $\mathrm{CO}_{2}$ fixation (NetFix), active $\mathrm{CO}_{2}$ (activeCO $\mathrm{CO}_{2}$ up), $\mathrm{HCO}_{3}^{-}$(activeHCO- up) and total inorganic carbon uptake (activeDICup), and net $\mathrm{CO}_{2}$ efflux (netCO${ }_{2}$ eff). The gray shaded area denotes the respiration rate in the dark within statistical boundaries (one standard deviation). The upper panel shows rates at $\left[\mathrm{Fe}(\mathrm{III})^{\prime}\right]$ replete, the middle at intermediate and the lower at deplete conditions. For corresponding growth rates and details on the fitting curves (solid lines) see Table 1 and Section 2.4, respectively.
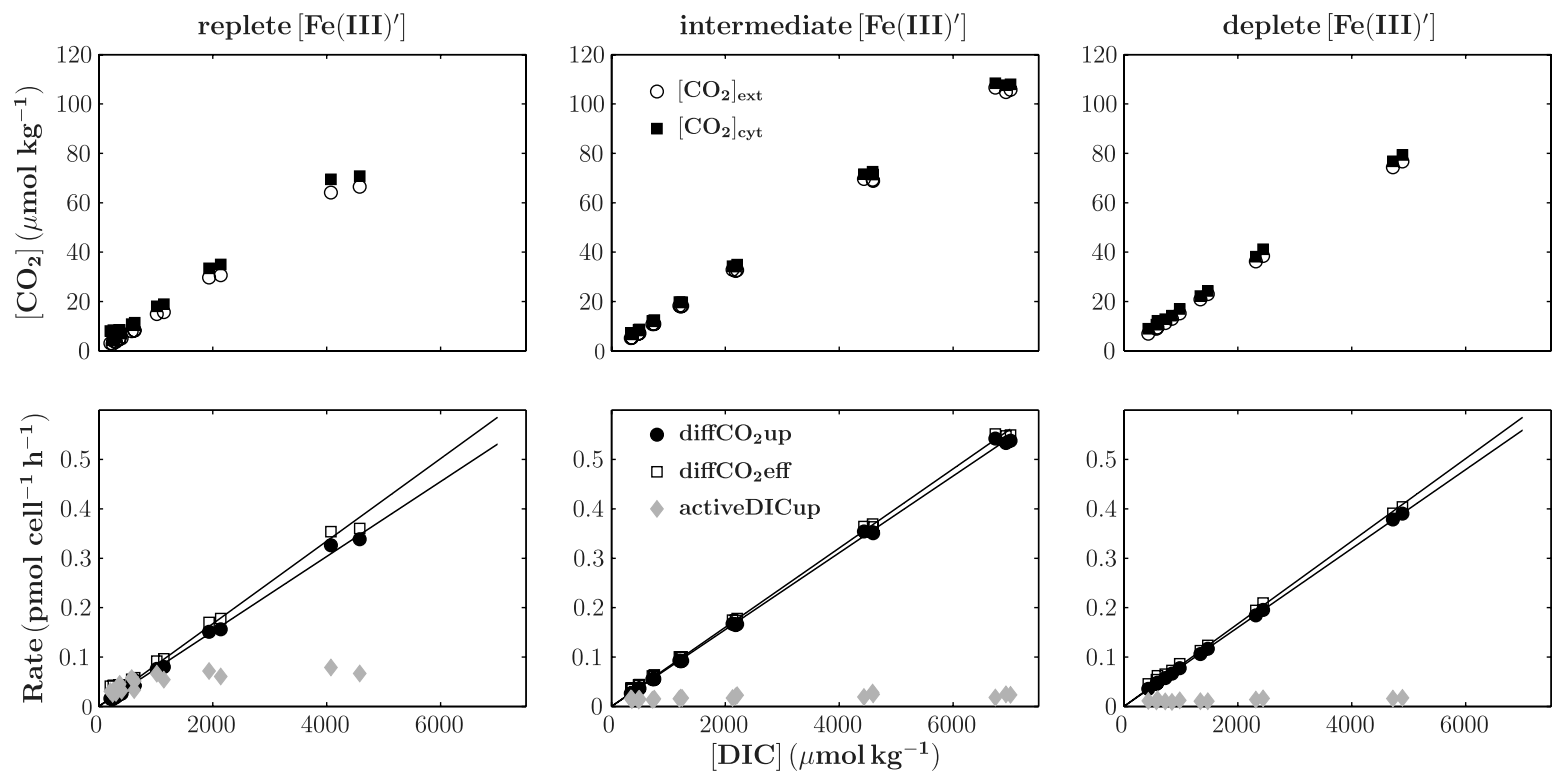

Fig. 4. External and cytosolic $\left[\mathrm{CO}_{2}\right]$ in relation to external [DIC] under iron replete, intermediate and deplete conditions (top). Resulting diffusive $\mathrm{CO}_{2}$ fluxes into (diffCO $\mathrm{Cu}_{2}$ ) and out of the cell (diffCO $\mathrm{Cff}_{2}$ in comparison to active DIC uptake rates (bottom). Plasmamembrane permeability was assumed to be $1.8 \times 10^{-5} \mathrm{~m} \mathrm{~s}^{-1}$ (Sültemeyer and Rinast, 1996). Solid lines mark linear fits (see Section 2.4 for details). Note that the diffusive $\mathrm{CO}_{2}$ efflux is always higher than the diffusive $\mathrm{CO}_{2}$ uptake. Hence, photosynthetic carbon fixation requires active DIC uptake.

respect to external $\mathrm{CO}_{2}\left(\epsilon_{\mathrm{p}}\right)$ of about $22.0 \%$, $27.0 \%$ and $28.3 \%$ under iron replete, intermediate and deplete conditions, respectively. These values are significantly higher than those measured in the second experimental approach, which, moreover, did not change with the degree of iron limitation but remained rather constant at about $12-13 \%$ (Table 3 ). 
Table 3

Specific growth rates $(\mu)$, carbon isotope fractionation $\left(\epsilon_{\mathrm{p}}\right)$ and ratio of particulate inorganic to particulate organic carbon (PIC/ POC) of Emiliania huxleyi grown at $\mathrm{pH}_{\mathrm{T}} 7.85$ and 8.3 under varying $\left[\mathrm{Fe}(\mathrm{III})^{\prime}\right]$

\begin{tabular}{lllll}
\hline & {$\left[\mathrm{Fe}(\mathrm{III})^{\prime}\right]$} & $\mu$ & $\epsilon_{\mathrm{p}}$ & $\mathrm{PIC} / \mathrm{POC}$ \\
\hline $\mathrm{pH}_{\mathrm{T}} 7.85$ & 132 & $1.00 \pm 0.00$ & $12.6 \pm 0.2$ & $0.55 \pm 0.02$ \\
& 4.8 & $0.83 \pm 0.01$ & $12.4 \pm 0.2$ & $0.55 \pm 0.02$ \\
& 2.9 & $0.74 \pm 0.00$ & $11.5 \pm 0.2$ & $0.54 \pm 0.04$ \\
& 0.96 & $0.41 \pm 0.01$ & $12.6 \pm 0.3$ & $0.54 \pm 0.06$ \\
& 0.06 & $0.23 \pm 0.00$ & $12.8 \pm 0.7$ & $0.58 \pm 0.01$ \\
$\mathrm{pH}_{\mathrm{T}} 8.3$ & 360 & $1.04 \pm 0.00$ & $13.8 \pm 0.3$ & $0.59 \pm 0.03$ \\
& 8.9 & $0.98 \pm 0.00$ & $11.7 \pm 0.1$ & $0.60 \pm 0.03$ \\
& 4.6 & $0.86 \pm 0.01$ & $13.9 \pm 0.5$ & $0.59 \pm 0.05$ \\
& 2.0 & $0.70 \pm 0.01$ & $12.6 \pm 0.1$ & $0.61 \pm 0.04$ \\
& 0.2 & $0.54 \pm 0.00$ & $15.6 \pm 0.3$ & $0.74 \pm 0.10$
\end{tabular}

Specific growth rates are reported in divisions per day, fractionation in permil and $\left[\mathrm{Fe}(\mathrm{III})^{\prime}\right]$, calculated as described in Schulz et al. (2004), in pmol kg-

While both, maximum rates of active $\mathrm{CO}_{2}$ and $\mathrm{HCO}_{3}^{-}$ uptake normalized to chlorophyll remained rather constant with increasing iron limitation, rates of net photosynthesis decreased, although not as pronounced as corresponding values normalized on a per cell basis (data not shown). Consequently, net $\mathrm{CO}_{2}$ efflux rates per unit of chlorophyll increased with increasing iron limitation. This is the result of markedly diminished chlorophyll $a$ content per cell which dropped from about 0.19 under iron replete to 0.02 pg per cell under iron deplete conditions (Table 1).

\section{DISCUSSION}

Iron limitation is a widespread phenomenon in large parts of today's oceans, comprising the Southern Ocean, parts of the North and the Equatorial Pacific. Hence, physiological responses of phytoplankton to iron limitation, in particular potential changes in modes of carbon acquisition and $\mathrm{CCM}$ activity are of great importance for our understanding of marine carbon cycling.

\subsection{Physiological response to iron limitation}

There are many physiological responses to iron limitation. Among those the most pronounced is the remodeling of the photosynthetic apparatus with the loss of functional PSII and most likely PSI reaction centers (Vassiliev et al., 1995), and PSI antenna complexes (Moseley et al., 2002). This leads to increased fluorescence of PSII and decreased chlorophyll $a$ content per cell, the so-called chlorosis. To which degree the reduction in cellular Chl $a$ due to iron limitation is part of the acclimation process itself or whether photosynthetic cells are simply not able to synthesize sufficient amounts of Chl $a$ because enzymes involved in its biosynthesis require iron as a co-factor, e.g. Chlorophyllide- $a$ oxygenase (Reinbothe et al., 2006), is not clear. However, whatever the mechanism, reduced amounts of cellular Chl $a$ help to prevent damage to the photosynthetic apparatus (see also Section 4.3). Furthermore, the cellular amount of various cytochromes involved in the photosynthetic electron transport are significantly reduced (Greene et al., 1992). Together, these processes result in diminished rates of electron transfer within the photosynthetic apparatus and reduced rates of net photosynthesis (Greene et al., 1991). Reduced growth (division) rates under iron limitation were reflected by the increasing importance of respiration in the dark over net photosynthesis in the light period (see Fig. 3 and Table 1). The concomitant down-regulation of active $\mathrm{CO}_{2}$ and $\mathrm{HCO}_{3}^{-}$uptake rates are most likely the result of both, diminished demand for inorganic carbon, and decreased capability to actively take it up. Demand for and uptake of inorganic carbon are ultimately determined by the amount of energy (ATP) and reductive power (NADPH) generated by electron transport within the photosynthetic apparatus. The ratio is adjusted by the relative proportions of linear (PSII $\rightarrow$ PSI $\rightarrow$ NADPH) to cyclic electron flow around PSI (only ATP generation) and Mehler reaction (PSII $\rightarrow$ PSI $\rightarrow \mathrm{O}_{2}$ ). In all three pathways, however, iron is an integral part of various electron transport components (e.g. cytochromes and FeS clusters). Thus, although the relative proportion of these pathways might change to some extent, iron limitation is likely to reduce both energy and reductive power supply. This, in turn, resulted in a reduction of active DIC uptake rates (Fig. 3). In contrast, the $\mathrm{CO}_{2}$ loss from the cells during photosynthesis (net $\mathrm{CO}_{2}$ efflux) was not as much reduced as the active DIC uptake (compare Fig. 3 and Table 2). In other words, when compared to the amount of DIC taken up actively, relatively more $\mathrm{CO}_{2}$ was lost from the cell. Also the ratio of active DIC uptake to fixation increased with iron limitation (Table 2), implying that in relation to fixation the cells increased their active uptake of inorganic carbon. In essence, these results indicate diminished CCM and carbon fixation efficiency under iron limitation.

\subsection{Carbon isotope fractionation}

Stable carbon isotope fractionation in marine phytoplankton has been shown to vary with changing environmental conditions such as temperature and $\left[\mathrm{CO}_{2}\right]$ (Freeman and Hayes, 1992; Goericke and Fry, 1994). More specifically, it has been suggested that $\epsilon_{\mathrm{p}}$ can be described by an inverse relationship between growth rate and $\mathrm{CO}_{2}$ concentration (Laws et al., 1995). Furthermore, it was pointed out that carbon isotope fractionation is affected by the kind of growth rate limiting resource (Riebesell et al., 2000). Surprisingly, although growth rates varied about 3-fold in this study, there was no change in carbon isotope fractionation (Table 2). These results seem to contradict the inorganic carbon flux measurements which show increasing leakage under iron limitation. However, it has to be kept in mind, that leakage is proportional to plasmamembrane permeability which is unfortunately poorly constrained and was assumed to be unaffected by iron limitation. Nevertheless, to match measured and flux-derived $\epsilon_{\mathrm{p}}$ values, plasmamembrane permeability would have to be reduced by about a factor of 20 under iron limitation which appears to be unlikely. Is there an alternative explanation for these seemingly contradicting results? 
Using Eq. (23) to derive $\epsilon_{\mathrm{p}}$ from flux measurements has an obvious drawback, since the cell is considered as a single compartment (compare Fig. 2). This is obviously far from a realistic representation of a cell's internal structure. Therefore a new model was constructed with an additional compartment, representing the chloroplast (Fig. 5). From a mass balance of the fluxes into and out of the two compartments, termed hereafter as the cytosol and the chloroplast, the stable carbon isotope fractionation $\left(\epsilon_{\mathrm{p}}\right)$ can be calculated. The mass balance for the carbon fluxes (sum of ${ }^{12} \mathrm{C}$ and ${ }^{13} \mathrm{C}$ species) in the cytosol reads

$$
\begin{aligned}
F_{\text {cyt }} \mathrm{CO}_{2}+F_{\text {cyt }} \mathrm{HCO}_{3}^{-}= & F_{\text {chl }} \mathrm{CO}_{2}+F_{\text {chl }} \mathrm{HCO}_{3}^{-} \\
& -F_{\text {chl }} \text { out }+F_{\text {cyt }} \text { out }
\end{aligned}
$$

and for the chloroplast

$F_{\text {chl }} \mathrm{CO}_{2}+F_{\text {chl }} \mathrm{HCO}_{3}^{-}=\mathrm{FIX}+F_{\text {chl }}$ out

From these total carbon fluxes ${ }^{13} \mathrm{C}$-fluxes can be derived by introducing the isotopic ratio $R$ of a carbon specimen defined as $R={ }^{13} \mathrm{C} /{ }^{12} \mathrm{C}$. Multiplying the total fluxes with the respective $R$ introduces an error in the mass balance be- expressed between $\mathrm{HCO}_{3}^{-}$and $\mathrm{CO}_{2}$ as $\alpha_{\mathrm{bd}}=1 / \alpha_{\mathrm{db}}$. In ana$\operatorname{logy}$, a fractionation factor $\alpha_{\mathrm{Rub}}$ is taken to describe the isotopic fractionation against ${ }^{13} \mathrm{C}$ by $\mathrm{Rubis} \mathrm{CO}$ associated with organic carbon fixation. Because $\alpha_{\mathrm{Rub}}$ is defined as $\alpha_{\mathrm{Rub}}=R_{\mathrm{CO}_{2}} / R_{\mathrm{POC}}$ it follows that $\alpha_{\mathrm{Rub}}=1+\epsilon_{\mathrm{Rub}} / 1000$. Hence, the mass balance for ${ }^{13} \mathrm{C}$ in the cytosol can be written as

$$
\begin{aligned}
R_{\mathrm{ext}} & F_{\mathrm{cyt}} \mathrm{CO}_{2}+\alpha_{\mathrm{bd}} R_{\mathrm{ext}} F_{\mathrm{cyt}} \mathrm{HCO}_{3}^{-} \\
= & R_{\mathrm{cyt}} F_{\mathrm{chl}} \mathrm{CO}_{2}+\alpha_{\mathrm{bd}} R_{\mathrm{cyt}} F_{\mathrm{chl}} \mathrm{HCO}_{3}^{-}-R_{\mathrm{chl}} F_{\mathrm{chl}} \text { out } \\
& \quad+R_{\mathrm{cyt}} F_{\mathrm{cyt}} \text { out }
\end{aligned}
$$

and in the chloroplast as

$$
\begin{aligned}
& R_{\mathrm{cyt}} F_{\mathrm{chl}} \mathrm{CO}_{2}+\alpha_{\mathrm{bd}} R_{\mathrm{cyt}} F_{\mathrm{chl}} \mathrm{HCO}_{3}^{-} \\
& \quad=R_{\mathrm{chl}} \mathrm{FIX} / \alpha_{\mathrm{Rub}}+R_{\mathrm{chl}} F_{\mathrm{chl}} \mathrm{Out}
\end{aligned}
$$

with $R_{\text {ext }}, R_{\text {cyt }}$ and $R_{\text {chl }}$ denoting the ratio between ${ }^{13} \mathrm{C}$ and ${ }^{12} \mathrm{C}$ of $\mathrm{CO}_{2}$ in the external medium, the cytosol and the chloroplast, respectively. Eq. (29) can be rearranged for $R_{\text {cyt }}$ and substituted into Eq. (28), which in turn is solved for $R_{\mathrm{chl}}$, resulting in

$R_{\mathrm{chl}}=\left(R_{\mathrm{ext}} F_{\mathrm{cyt}} \mathrm{CO}_{2}+\alpha_{\mathrm{bd}} R_{\mathrm{ext}} F_{\mathrm{cyt}} \mathrm{HCO}_{3}^{-}\right) /\left[\frac{\left(\mathrm{FIX} / \alpha_{\mathrm{Rub}}+F_{\mathrm{chl}} \mathrm{out}\right)\left(F_{\mathrm{chl}} \mathrm{CO}_{2}+\alpha_{\mathrm{bd}} F_{\mathrm{chl}} \mathrm{HCO}_{3}^{-}+F_{\mathrm{cyt}} \text { out }\right)}{F_{\mathrm{chl}} \mathrm{CO}_{2}+\alpha_{\mathrm{bd}} F_{\mathrm{chl}} \mathrm{HCO}_{3}^{-}}-F_{\mathrm{chl}}\right.$ out $]$

cause ${ }^{12} \mathrm{C}$ and the total amount of carbon are not identical. However, this error will be small for carbon as about $99 \%$ of carbon is ${ }^{12} \mathrm{C}$. As $\mathrm{HCO}_{3}^{-}$is about $10 \%$ enriched in ${ }^{13} \mathrm{C}$ compared to $\mathrm{CO}_{2}$ this fractionation is taken into account by introducing a fractionation factor $\alpha_{\mathrm{db}}$ between $\mathrm{CO}_{2}$ and $\mathrm{HCO}_{3}^{-}$defined as $\alpha_{\mathrm{db}}=R_{\mathrm{CO}_{2}} / R_{\mathrm{HCO}_{3}^{-}}$. It is calculated from the fractionation $\epsilon_{\mathrm{db}}$ given by Mook (1986) as $\alpha_{\mathrm{db}}=1+\epsilon_{\mathrm{db}} / 1000$. For convenience the fractionation is



Fig. 5. Intracellular carbon fluxes in a cell with two compartments, the cytosol and the chloroplast (shown in gray). $F_{\text {cyt }}$ denote the fluxes of $\mathrm{CO}_{2}$ and $\mathrm{HCO}_{3}^{-}$from the external medium into the cytosol, and $F_{\text {cyt }}$ out the $\mathrm{CO}_{2}$ flux out of the cytosol. Similarly, $F_{\text {chl }}$ represents the fluxes from the cytosol into the chloroplast, and $F_{\text {chl }}$ out the corresponding $\mathrm{CO}_{2}$ flux out of the chloroplast. $\epsilon_{\mathrm{Rub}}$ illustrates the fractionation of RubisCO associated with carbon fixation.
Fractionation between external $\mathrm{CO}_{2}$ and the particulate organic matter produced during carbon fixation is then given as

$\epsilon_{\mathrm{p}}=\left(\alpha_{\mathrm{Rub}} \frac{R_{\mathrm{ext}}}{R_{\mathrm{chl}}}-1\right) \times 1000$

Note that fractionation is independent of the external isotopic composition of $\mathrm{CO}_{2}$ as it is defined relative to $\mathrm{R}_{\text {ext }}$.

The simple relation between 'external' carbon fluxes $\left(F_{\text {cyt }} \mathrm{CO}_{2}, F_{\text {cyt }} \mathrm{HCO}_{3}^{-}\right)$, fixation and fractionation presented in Eq. (23) (note that diffCO ${ }_{2}$ eff equals DICup - NetFix) now becomes more complicated (Eqs. (26)-(30)). Fractionation depends on the relation between external and internal' $\left(F_{\text {chl }} \mathrm{CO}_{2}, F_{\text {chl }} \mathrm{HCO}_{3}^{-}\right)$fluxes. For a measured fixation rate and respective external fluxes, the fractionation is constrained by the ratio of the internal fluxes to fixation, hence by the relation of internal to external fluxes (Fig. 6). Generally, the higher the internal fluxes compared to fixation, the higher the fractionation as the heavy ${ }^{13} \mathrm{C}$ is not accumulating at the site of carboxylation. Furthermore, $\mathrm{HCO}_{3}^{-}$uptake into an internal cellular compartment such as a chloroplast reduces apparent fractionation. Maximum attainable fractionation is set by the relation of the external fluxes to fixation, as predicted by Eq. (23), and is approached when the internal fluxes exceed those of fixation by more than an order of magnitude (Fig. 6). This demonstrates the importance of the internal inorganic carbon fluxes in modulating the apparent stable carbon isotope fractionation. In comparison to non-limiting conditions active uptake of $\mathrm{CO}_{2}$ and $\mathrm{HCO}_{3}^{-}$into the cell were largely diminished (compare Table 2). Therefore it is conceivable that iron limitation, hence energy limitation, also leads to 




Fig. 6. Stable carbon isotope fractionation $\left(\epsilon_{\mathrm{p}}\right)$ as predicted by the model with an inner cellular compartment (compare Fig. 5) at constant external and variable internal fluxes (see text for details). The solid line shows fractionation if the $\mathrm{HCO}_{3}^{-}$fraction of the internal flux is zero, while the dotted and dashed lines show the fractionation for a $\mathrm{HCO}_{3}^{-}$contribution of 0.5 and 1, respectively. The gray shaded horizontal bar illustrates the corresponding fractionation as predicted by the modified Sharkey and Berry (1985) model. External fluxes and fixation were chosen to resemble those measured for intermediate iron conditions.

to reduced concentrating fluxes into the chloroplast, the site of fixation. Indeed, reduced $\left[\mathrm{CO}_{2}\right]$ in the chloroplast were suggested for energy (light) limited growth in a two compartment cell model developed recently by Cassar et al. (2006). The complex interplay and regulation of both, external and internal inorganic carbon fluxes could therefore be responsible for the observed pattern in stable carbon isotope fractionation.

\subsection{Iron versus light limitation}

For phytoplankton cells, iron limitation poses a severe problem, i.e a reduction in energy available for cellular processes. Although the chlorophyll content per cell decreases under iron limitation and increases under light limitation, these responses can be seen as the two sides of the same coin. While the first prevents damage to the photosynthetic apparatus because electrons cannot be transported at maximum speed to the terminal electron acceptor, the second is employed to compensate for the reduced amounts of photons reaching the antenna complexes of PSI and PSII. Nevertheless, both limitations will results in a strong reduction of electrons transported and therefore energy availability will be reduced. Interestingly, measured carbon isotope fractionation in E. huxleyi under various light/dark cycles showed only relatively small variations $(3-4 \%$ o) to changes in light intensity, although growth rates varied by a factor of two (Rost et al., 2002). This suggests that total carbon fluxes (external and internal) under light limitation are likely to be equally affected as by iron limitation. The insensitivity of $\epsilon_{\mathrm{p}}$ to a 3-fold decrease in growth rate due to lower light intensities was also observed in a marine diatom (Riebesell et al., 2000).

\subsection{Implications for paleoreconstructions}

The apparent lack of any significant response in $\epsilon_{\mathrm{p}}$ to changes in the degree of iron limitation may be of potential interest for the interpretation of sedimentary records of carbon isotope data in today's HNLC areas of the ocean. Here, the diverse group of diatoms is dominating the phytoplankton biomass. If the results of this study prove to equally apply to marine diatoms, higher dust and therefore iron input to today's HNLC regions in glacial times (Mahowald et al., 1999) should increase diatom growth rates but at the same time leave their individual carbon isotope fractionation unaffected. Any change in the isotopic composition of bulk organic matter should therefore reflect changes in the biomass contributions of individual diatom species. Indeed, Trull and Armand (2001) found that while $\delta^{13} \mathrm{C}_{\text {org }}$, the isotopic composition of POC, in different size classes of phytoplankton was quite insensitive to iron additions in the Southern Ocean, phytoplankton in the range between 1 and $5 \mu \mathrm{m}$ was about $8 \%$ more depleted in ${ }^{13} \mathrm{C}$ in comparison to phytoplankton in the range of 20 $70 \mu \mathrm{m}$. Additionally, the temporal increase in bulk $\delta^{13} \mathrm{C}_{\mathrm{org}}$ upon iron additions observed by Trull and Armand (2001) confirmed results by Bidigare et al. (1999) who observed a $\sim 7 \%$ increase of $\delta^{13} \mathrm{C}_{\text {phytol}}$, the isotopic composition of the biomarker phytol, upon several additions of iron in the equatorial Pacific. This implies that the increase (lower ${ }^{13} \mathrm{C}$ depletion) of $\delta^{13} \mathrm{C}_{\text {org }}$ or $\delta^{13} \mathrm{C}_{\text {phytol }}$ was likely related to a change in phytoplankton community structure from smaller to larger cells (most likely diatoms) upon alleviation of iron limitation. Hence, $\delta^{13} \mathrm{C}_{\mathrm{org}}$ in the sedimentary record of today's HNLC areas may preserve information on the contribution of larger phytoplankton cells to total biomass. As larger phytoplankton dominates in these regions when primary production is stimulated by alleviation of iron limitation, we hypothesize that sedimentary $\delta^{13} \mathrm{C}_{\mathrm{org}}$ may therefore be indicative for changes in the strength of marine carbon sequestration.

\section{CONCLUSIONS}

In this study we have investigated the influence of iron limitation on growth, photosynthesis, inorganic carbon acquisition, carbon concentrating mechanism (CCM) activity and efficiency and stable carbon isotope fractionation in the coccolithophore Emiliania huxleyi. We show that the reduction of photosynthetic carbon fixation, hence cellular growth rates, under iron limitation are the result of decreased active $\mathrm{CO}_{2}$ and $\mathrm{HCO}_{3}^{-}$uptake fluxes, and decreased $\mathrm{CCM}$ and carbon fixation efficiency. Furthermore we present an analysis of the complex interplay of 'external' (external media $\leftrightarrow$ cytosol) and 'internal' (cytosol $\leftrightarrow$ chloroplast) inorganic carbon fluxes and discuss its implication for stable carbon isotope fractionation, ultimately linked to CCM activity and efficiency.

\section{ACKNOWLEDGMENTS}

We gratefully thank K.-U. Richter and A. Terbrüggen for technical assistance and R.E. Zeebe for vital discussions on stable car- 
bon isotope fractionation. We also acknowledge Hein de Baar and two anonymous reviewers for their helpful comments.

\section{REFERENCES}

Badger M. R., Palmqvist K. and Yu J.-W. (1994) Measurement of $\mathrm{CO}_{2}$ and $\mathrm{HCO}_{3}^{-}$fluxes in cyanobacteria and microalgae during steady-state photosynthesis. Physiol. Plant 90, 529-536.

Badger M. R., Andrews T., Whitney S. M., Ludgwig M., Yellowlees D. C., Leggat W. and Price G. D. (1998) The diversity and coevolution of Rubisco, plastids, pyrenoids, and chloroplast-based $\mathrm{CO}_{2}$-concentrating mechanisms in algae. Can. J. Bot. 76, 1052-1071.

Beardall J. (1991) Effects of photon flux density on the ' $\mathrm{CO}_{2}$ concentrating mechanism' of the cyanobacterium Anabaena variabilis. J. Plankt. Res. 13, 133-141.

Bidigare R. R., Hanson K. L., Buesseler K. O., Wakeham S. G., Freeman K. H., Pancost R. D., Millero F. J., Steinberg P., Popp B. N., Latasa M., Landry M. R. and Laws E. A. (1999) Iron-stimulated changes in ${ }^{13} \mathrm{C}$ fractionation and export by equatorial Pacific phytoplankton: toward a paleogrowth rate proxy. Paleoceanography 14, 589-595.

Buitenhuis E. T., Timmermans K. R. and de Baar H. J. W. (2003) Zinc-bicarbonate colimitation of Emiliania huxleyi. Limnol. Oceanogr. 48, 1575-1582.

Burkhardt S., Riebesell U. and Zondervan I. (1999) Effects of growth rate, $\mathrm{CO}_{2}$ concentration, and cell size on the stable carbon isotope fractionation in marine phytoplankton. Geochim. Cosmocim. Acta 63, 3729-3741.

Burkhardt S., Amoroso G., Riebesell U. and Sültemeyer D. (2001) $\mathrm{CO}_{2}$ and $\mathrm{HCO}_{3}^{-}$uptake in marine diatoms acclimated to different $\mathrm{CO}_{2}$ concentrations. Limnol. Oceanogr. 46, 1378-1391.

Cassar N., Laws E. A. and Popp B. N. (2006) Carbon isotopic fractionation by the marine diatom Phaeodactylum tricornutum under nutrient and light-limited growth conditions. Geochim. Cosmochim. Acta 70, 5323-5335.

Davison I. (1987) Adaption of photosynthesis in Laminaria saccarina (Phaeophyta) to changes in growth temperature. $J$. Phycol. 23, 273-283.

de Baar H. J. W. and Boyd P. W. (2000). In The Role of Iron in Plankton Ecology and Carbon Dioxide Transfer of the Global Oceans (eds. R. B. Hanson, H. W. Dicklow and J. G. Fields), pp. 61-140. The Changing Ocean Carbon Cycle. Cambridge University Press, Cambridge.

Dickson A. G. and Millero F. J. (1987) A comparison of the equilibrium constants for the dissociation of carbonic acid in seawater media. Deep-Sea Res. 34, 1733-1743.

DOE (1994) Handbook of Methods for the Analysis of the Various Parameters of the Carbon Dioxide System in Seawater, version 2. (eds. A. G. Dickson and C. Goyet), ORNL/CDIAC-74.

Falkowski P. G. and Raven J. (1997) Aquatic Photosynthesis. Blackwell Science, Oxford.

Farquhar G. D., O’Leary M. H. and Berry J. A. (1982) On the relationship between carbon isotope discrimination and the intercellular carbon dioxide concentration in leaves. Aust. $J$. Plant Physiol. 9, 121-137.

Freeman K. H. and Hayes J. M. (1992) Fractionation of cabon isotopes by phytoplankton and estimates of ancient $\mathrm{CO}_{2}$ levels. Glob. Biochem. Cycl. 6, 185-198.

Garcia H. E. and Gordon L. I. (1992) Oxygen solubility in seawater: better fitting equations. Limnol. Oceanogr. 37, 13071312.

Goericke R. and Fry B. (1994) Variations of marine plankton $\delta^{13} \mathrm{C}$ with latitude, temperature, and dissolved $\mathrm{CO}_{2}$ in the world ocean. Glob. Biochem. Cycles 8, 85-90.
Greene R. M., Geider R. J. and Falkowski P. G. (1991) Effect of iron limitation on photosynthesis in a marine diatom. Limnol. Oceanogr. 36, 1772-1782.

Greene R. M., Geider R. J., Kolber Z. and Falkowski P. G. (1992) Iron-induced changes in light harvesting and photochemical energy conversion processes in eukaryotic marine algae. Plant Physiol. 100, 565-575.

Laws E. A. (1991) Photosynthetic quotients, new producion and net community production in the open ocean. Deep-Sea Res. 38, 143-167.

Laws E. A., Popp B. N., Bidigare R. R., Kennicutt M. C. and Macko S. A. (1995) Dependence of phytoplankton carbon isotopic composition on growth rate and $\left[\mathrm{CO}_{2}\right]_{\mathrm{aq}}$ : theoretical considerations and experimental results. Geochim. Cosmochim. Acta 59, 1131-1138.

Laws E. A., Popp B. N., Cassar N. and Tanimoto J. (2002) ${ }^{13}$ C discrimination patterns in oceanic phytoplankton: likely influence of $\mathrm{CO}_{2}$ concentrating mechanisms, and implications for paleoreconstructions. Funct. Plant Biol., 323-333.

Mahowald N., Kohfeld K., Hansson M., Balkanski Y., Harrison S. P., Prentice I. C., Schulz M. and Rodhe H. (1999) Dust sources and deposition during the last glacial maximum and current climate: a comparision of model results with paleodata from ice cores and marine sediments. $J$. Geophys. Res. 104, 15895-15916.

Mehrbach C., Culberson C. H., Hawley J. E. and Pytkowicz R. N. (1973) Measurement of the apparent dissociation constants of carbonic acid in seawater. Limnol. Oceanogr. 18, 897-907.

Mook W. G. (1986) ${ }^{13} \mathrm{C}$ in atmospheric $\mathrm{CO}_{2}$. Neth. J. Sea Res. 20, 211-223.

Moseley J. L., Allinger T., Herzog S., Hoerth P., Wehinger E., Merchant S. and Hippler M. (2002) Adaptation to Fedeficiency requires remodeling of the photosynthetic apparatus. EMBO J. 21, 6709-6720.

Raven J. A. (1980) Nutrient transport in microalgae. Adv. Microb. Physiol. 21, 47-226.

Raven J. A. (1997) norganic carbon acquisition by marine autotrophs. Adv. Bot. Res. 27, 85-209.

Raven J. A. and Lucas W. J. (1985) Energy costs of carbon acquisition. In Inorganic Carbon Uptake by Aquatic Photosynthetic Organisms (eds. W. J. Lucas and J. A. Berry). American Society of Plant Physiologists, Rockville MD. pp. 305-324.

Raven J. A., Johnston A. M., Kübler J. E., Korb R. E., McInroy S. G., Handley L. L., Scrimgeour C. M., Walker D. I., Beardall J., van der klift M., Fredriksen S. and Dunton J. H. (2002) Mechanistic interpretation of carbon isotope discrimination by marine macroalgae and seagras. Funct. Plant Biol. 29, 355-378.

Reinbothe C., Bartsch S., Eggink L. L., Hoober J. K., Brusslan J., Andrade-Paz R., Monnet J. and Reinbothe S. (2006) A role for chlorophyllide a oxygenase in the regulated import and stabilization of light-harvesting chlorophyll $a / b$ proteins. Proc. Natl. Acad. Sci. USA 103, 4777-4782.

Riebesell U., Burkhardt S., Dauelsberg A. and Kroon B. (2000) Carbon isotope fractionation by a marine diatom: dependence on the growth-rate-limiting resource. Mar. Ecol. Progr. Ser. 193, 295-303.

Roeske C. and O'Leary M. (1984) Carbon isotope effects on the enzyme-catalyzed carboxilation of ribulose bisphosphate. Biochemistry 23, 6275-6285.

Rost B., Zondervan I. and Riebesell U. (2002) Light-dependent carbon isotope fractionation in the coccolithophore Emiliania huxleyi. Limnol. Oceanogr. 47, 120-128.

Rost B., Riebesell U., Burkhardt S. and Sültemeyer D. (2003) Carbon acquistion of bloom-forming marine phytoplankton. Limnol. Oceanogr. 48, 55-67. 
Rost B., Riebesell U. and Sültemeyer D. (2006) Carbon acquisition of marine phytoplankton: effect of photoperiod length. Limnol. Oceanogr. 51, 12-20.

Schulz K. G., Zondervan I., Gerringa L. J. A., Timmermans K. R., Veldhuis M. J. W. and Riebesell U. (2004) Effect of trace metal availability on coccolithophorid calcification. Nature 430, 673676.

Schulz K. G., Riebesell U., Rost B., Thoms S. and Zeebe R. E. (2006) Determination of the rate constants for the carbon dioxide to bicarbonate inter-conversion in $\mathrm{pH}$-buffered seawater systems. Mar. Chem. 100, 53-65.

Sharkey T. D. and Berry J. A. (1985) Carbon isotope fractionation of algae as influenced by an inducible $\mathrm{CO}_{2}$ concentrating mechanism. In Inorganic Carbon Uptake by Aquatic Photosynthetic Organisms (eds. W. J. Lucas and J. A. Berry). American Society of Plant Physiologists, Rockville MD.

Stoll M. H. C., Bakker K., Nobbe G. H. and Haese R. R. (2001) Continuous flow analysis of dissolved inorganic carbon content in seawater. Anal. Chem. 73, 4111-4116.

Strickland J. D. H. and Parsons T. R. (1968) A practical handbook of seawater analysis. Bull. Fish. Res. Bd. Canada, 167.

Sültemeyer D. and Rinast K.-A. (1996) The $\mathrm{CO}_{2}$ permeability of the plasma membrane of Chlamydomonas reinhardtii: mass- spectrometric ${ }^{18} \mathrm{O}$-exchange measurements from ${ }^{13} \mathrm{C}^{18} \mathrm{O}_{2}$ in suspensions of carbonic anhydrase-loaded plasma-membrane vesicles.. Planta 200, 358-368.

Thoms S., Pahlow M. and Wolf-Gladrow D. (2001) Model of the carbon concentrating mechanism in chloroplasts of eukaryotic algae. J. Theor. Biol. 208, 295-313.

Trull T. W. and Armand L. (2001) Insights into Southern Ocean carbon export from $\delta^{13} \mathrm{C}$ of particles and dissolved inorganic carbon during the SOIREE iron release experiment. Deep-Sea Res. 48, 2655-2680.

Vassiliev I. R., Kolber Z., Wyman K., Mauzerall D., Shukla V. K. and Falkowski P. G. (1995) Effects of iron limitation on photosystem II composition and light utilization in Dunaliella teriolecta. Plant Physiol. 109, 963-972.

Zeebe R. E. and Wolf-Gladrow D. (2001) $\mathrm{CO}_{2}$ in Seawater: Equilibrium, Kinetics, Isotopes. Vol. 65. Elsevier Oceanography Series. Elsevier, Amsterdam.

Zhang J., Quay P. D. and Wilbur D. O. (1995) Carbon isotope fractionation during gas-water exchange and dissolution of $\mathrm{CO}_{2}$. Geochim. Cosmochim. Acta 59, 107-114.

Associate editor: Jack J. Middelburg 